\title{
Empire by Consent: Strakhov, Dostoevskii, and the Polish Uprising of 1863
}

\section{EDYTA M. BOJANOWSKA}

In this article Edyta Bojanowska explores the circumstances surrounding the publication, in 1863 in the Dostoevskii brothers' journal Vremia, of a pro-Polish article by Nikolai Strakhov that led to the journal's closing. Bojanowska argues against accepting Strakhov's and Fedor Dostoevskii's retroactive explanations that the article was misunderstood. She analyzes Strakhov's article and the entire issue of Vremia in which it appeared and finds a consistent message in both: that Russia should withdraw from Poland, where imperial success would be either unlikely or too costly, shift its attention from imperial expansion to a domestic agenda, and restructure the empire into one based on the constituent populations' consent. Given Dostoevskii's endorsement of Strakhov's article and his hands-on editorial work on Vremia, this affair suggests a tolerant and pragmatic phase in Dostoevskii's imperial ideology that contrasts with the militant imperialistic punditry of his later period.

\section{Holidays in Kazan: The Public Sphere and the Politics of Religious Authority among Tatars in 1914}

\section{NoriHiro Naganawa}

This article demonstrates that it was the public sphere shaped by the Kazan city duma and the local press, rather than the tsarist state alone, that strengthened Muslim identity among the urban Tatars. Norihiro Naganawa argues that the invocation of the empire's ruling principle of religious tolerance split the duma along confessional lines and undermined its arbitrating role. He also examines the political discussions among the local Tatar intellectuals over the timing and meaning of Islamic holidays. While the Spiritual Assembly, the long-standing hub of Muslim-state interaction, provided leverage for the mullahs in their efforts to maintain a secure domain for religion, this security dissipated as it became entangled in the competition for authority among increasingly numerous actors speaking for Islam and nation. Naganawa also suggests that late imperial Russia was confronted by the profound theoretical challenge of religious pluralism, to which not tsarism, nor liberal democracy, nor secularism had or have easy answers.

\section{Sergei Eisenstein's Ivan the Terrible and the Renaissance: An Example of Stalinist Cosmopolitanism?}

Katerina Clark

In this article Katerina Clark argues that Sergei Eisenstein's Ivan the Terrible trilogy should not be taken as an unambiguous example of the revival of the national in Stalinist culture of the 1930s and 1940s. Clark identifies 
Eisenstein as a "cosmopolitan patriot" and proposes that the film can be interpreted, inter alia, in terms of this orientation, focusing on the role of the west European Renaissance in the film. This link is explicit in the Prologue and in an article by Eisenstein, which equate Ivan's ruthless exercise of power and use of violence with the record of such Renaissance giants as Henry VIII and Catherine de Medici. But the link is also implicit in some of the visual imagery and the plot structure (which draws on the Elizabethan revenge tragedy). In such allusions to the Renaissance, Clark contends, Eisenstein was effectively entering into European debates of the fascist era about "humanism," "cosmopolitanism," and internationalism, with a position that emerges as both nuanced and conflicted.

\section{Samizdat and Soviet Dissident Publics}

\section{AnN Komaromi}

In this article Ann Komaromi proposes a new critical look at the history of Soviet dissidence by way of samizdat and the idea of a private-public sphere. Samizdat is defined in a less familiar way, as a particular mode of existence of the text, rather than in terms of political opposition or a social agenda. This allows for a broader view of dissidence that includes familiar phenomena like the civil rights or democratic movement, along with relatively little known national, cultural, musical, artistic, poetic, and philosophical groups. The multiple perspectives of Soviet dissidence correspond to a decentered view of a mixed private-public sphere that resembles Nancy Fraser's modification of Jürgen Habermas's classic public sphere. This model of a private-public sphere provokes new questions about unofficial institutions and structures, the dialectic between private and public impulses in Soviet samizdat, and the relationship of dissidents to foreign individuals and organizations. The empirical basis for this analysis is a survey of Soviet samizdat periodicals from 1956 to 1986.

\section{The Russian-Speaking Jewish Diaspora in Translation: Liudmila Ulitskaia's Daniel Stein, Translator}

\section{Margarita Levantovskaya}

Liudmila Ulitskaia's 2006 novel, Daniel' Shtain, pervodchik (Daniel Stein, Translator), explores the experience of the Russian-speaking diaspora in the aftermath of World War II through a focus on Jewish immigrants in Israel who convert to Christianity. The novel's treatment of the divisive topic of Jewish to Christian conversion is enabled by the author's reliance on the theoretical and allegorical values of translation. Evoking advancements in twentieth-century translation studies through its broad treatment of translation and critique of the investment in the notion of fidelity to the original, be it language or identity, the novel advocates for the acceptance of the transformations and the resulting hybridity of the Jewish diasporic self. Daniel Stein, Translator specifically highlights the influence of the Soviet nationalities policies and the Nazi occupation of eastern Europe on the identity metamorphoses of Soviet Jews. By promoting the 
legitimacy of the expressions of Jewish identity by immigrants from the USSR through her novel, Ulitskaia proposes an expanded and anti-essentialist view of Jewish identity that would include individuals traditionally viewed as apostates.

\section{Black Work, Green Money: Remittances, Ritual, and Domestic Economies in Southern Kyrgyzstan}

\section{Madeleine ReEves}

Drawing on ethnographic and survey data, Madeleine Reeves explores the meanings and impact of large-scale seasonal labor migration to Russia on a group of four kin-related villages in southern Kyrgyzstan. Although remittances have come to figure centrally in domestic budgets of migrant families, it is to questions of political economy that we must turn to understand the shift away from small-scale farming toward migrant work. Reeves examines a range of factors mediating decisions to migrate, including the role of social networks and sibling hierarchies; the emergence of growing economic differentials between migrant and nonmigrant households, and the growing importance for young men of a period of work "in town" (shaarda) in proving their eligibility for marriage. Although patterns of economic activity in southern Kyrgyzstan have changed dramatically in recent years, Reeves argues that new forms of engagement in distant labor markets are also being used to sustain patterns of ritual gifting and expressions of ethnic and religious identity that are imagined and articulated precisely as expressions of social continuity. 